\title{
Analisis kelimpahan E.coli dan bakteri Patogen sebagai indikator penurunan kualitas perairan pada budidaya keramba apung ikan patin desa Buluh Cina Kabupaten Kampar
}

\author{
Mumin Rifai ${ }^{1}$, Zulkarnaini ${ }^{2}$, Sofyan Husein Siregar ${ }^{2}$ \\ ${ }^{1}$ PHPI SKIPM Pekanbaru \\ ${ }^{2}$ Pascasarjana Ilmu Lingkungan Program Pascasarjana Universitas Riau
}

\begin{abstract}
The research on Escherichia coli (E. coli) and bacterial pathogens within catfish culture in Buluh Cina Village has been done in August 2015. This study aimed to analyze the quality of the river water, the abundance of E.coli in the water stream and pathogenic bacteria in catfish and to correlate the quality of the water with an abundance of $E$. coli and the prevalence of pathogenic bacteria. The location of the study is three observation stations with sampling conducted by three replications. The water quality parameters under investigation were temperature, brightness, $p H$, DO, Nitrate, Nitrite, Ammonia, Phosphate, TSS and BOD while the indicator for microbiological contamination is done by testing the abundance of E. coli in the river water as well as the pathogenic bacteria in catfish. The results of water quality measurements and testing of E. coli indicate the water quality is still good with the standard required under Regulation No 82/2001 except ammonia, phosphates, nitrites and E. coli. Ammonia has exceeded the threshold value with the average from 0.018 to $0.059 \mathrm{mg} / \mathrm{L}$, the phosphate on the average value of 4,921 to 9,804 $\mathrm{mg} / \mathrm{L}$, nitrite in the average value from 0.015 to $0.068 \mathrm{mg} / \mathrm{L}$ and the abundance of E. coli on the value of the average 4,200-5,500 cfu / $100 \mathrm{ml}$. While the results of testing on pathogenic bacteria found in catfish are Aeromonas sp, Pseudomonas sp, Pasteurella sp and Edwardsiella sp. The highest prevalence of pathogenic bacteria obtained in Aeromonas sp is equal to 29.63\%. In the statistical test toward chemical parameters of water measured affects the abundance of E. coli by $94 \%$. The most significant variable on the water quality parameters affecting the abundance of $E$. coli is the temperature, TSS, $p H$, and DO with a correlation coefficient $>0.5$.
\end{abstract}

\section{Keywords: Abundance of E. coli, Bacterial Pathogens, Water Quality}

Sungai Kampar merupakan aliran sungai yang berhulu di Sumatera Barat dan bermuara di Teluk Meranti Kabupaten Pelalawan. Aliran sungai tersebut melewati pemukiman yang berada di Desa Buluh Cina dengan tingkat hunian masyarakat cukup tinggi dan telah dimanfaatkan untuk keperluan mandi, cuci dan kakus, penangkapan ikan serta kegiatan budidaya ikan dengan sistem keramba apung. Pemanfaatan sungai sebagai sarana air bersih tersebut perlu adanya pengelolaan yang baik sehingga bisa berkelajutan dan tidak tercemari oleh aktifitas masyarakat akibat limbah domestik yang langsung dibuang ke aliran sungai dan dampak negatif lainya dari kegiatan budidaya ikan keramba apung yang turut merusak kualitas air.

Pembuangan limbah domestik rumah tangga ini akan menimbulkan dampak negatif terhadap kualitas air karena dapat menimbulkan tingkat kelimpahan bakteri Escherichia coli (E. coli) yang tinggi. Kelimpahan bakteri ini dapat dipicu oleh limbah kotoran tinja manusia maupun kotoran hewan yang berakibat dapat menimbulkan gangguan pada kesehatan manusia. Adapun kotoran hewan yang dikhawatirkan dapat meningkatkan kelimpahan bakteri E. coli di aliran Sungai Kampar Desa Buluh Cina berasal dari usus ayam dan/atau ayam mati yang digunakan sebagai makanan ikan di keramba. Pentingnya kualitas air yang baik, selain untuk kegiatan mandi, cuci dan kakus adalah untuk keberlajutan usaha pengembangan budidaya ikan di keramba apung yang selama ini telah digeluti oleh masyarakat Buluh Cina sebagai salah satu mata pencaharian.

Keberhasilan panen ikan merupakan suatu harapan yang dapat meningkatkan penghasilan masyarakat. Namun kegagalan panen ikan sering di alami oleh masyarakat karena serangan penyakit pada ikan akibat kualitas air yang buruk. Mengingat tingkat hunian masyarakat di Desa Buluh Cina semakin meningkat, aktivitas budidaya ikan terus berkembang dan informasi mengenai kelimpahan bakteri $E$. coli serta keragaman jenis bakteri patogen pada ikan masih sangat minim maka dilakukan penelitian dengan judul "Analisis Kelimpahan Bakteri E. coli dan Bakteri Patogen Sebagai Indikator Penurunan Kualitas Perairan Pada budidaya Ikan Patin Desa Buluh Cina Kabupaten Kampar". 


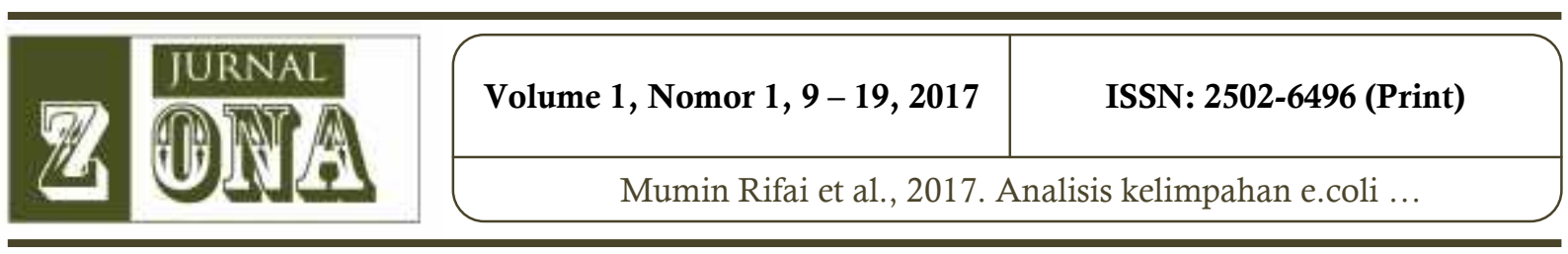

Penelitian ini bertujuan untuk menganalisis status kualitas lingkungan perairan sungai di Desa Buluh Cina, menganalisis kelimpahan bakteri E. coli pada air dan prevalensi bakteri patogen pada ikan patin, dan menganalisis hubungan antara kualitas lingkungan perairan dengan kelimpahan bakteri $E$. coli pada air dan prevalensi bakteri patogen pada ikan patin. Hasil penelitain ini diharapkan memberikan informasi kepada masyarakat tentang status kualitas air sungai di Desa Buluh Cina, sebagai acuan pemerintah pusat, pemerintah daerah dan instansi terkait lainya dalam melakukan perencanaan dan pertimbangan dalam pengambilan kebijakan terhadap pengelolaan air sungai yang ada di sekitar aliran sungai di Desa Buluh Cina dan sebagai pengembangan ilmu pengetahuan yang berhubungan dengan analisis kelimpahan bakteri E. coli pada air dan prevalensi bakteri patogen pada ikan patin dalam pengelolaan status kualitas air.

\section{METODE PENELITIAN}

\section{Sampel Air dan Ikan Patin.}

Pengujian bakteri E.coli dari sampel air yang diambil dari tiga stasiun pengamatan di Desa Buluh Cina, yaitu Stasiun 1 yang mewakili daerah hulu, stasiun 2 mewakili daerah tengah dan stasiun 3 yang mewakili daerah hilir dengan tiga kali periode pengambilan sampel. Parameter kualitas air yang diukur adalah Suhu, pH, Kecerahan, DO, Nitrat, Nitrit, Ammonia, Fosfat, TSS, dan BOD. Pengambilan sampel air untuk pengujian E.coli berpedoman pada SNI 01-2332-.1-2006 tentang cara uji mikrobiologi dalam penentuan E.coli. Identifikasi bakteri E.coli pada air sungai dilakukan dengan mengambil contoh air pada air permukaan secara aseptik dengan menggunakan botol steril sebanyak $100 \mathrm{ml}$ pada masing-masing stasiun penelitian. Pengawetan sampel dilakukan dengan memasukkannya kedalam kotak es (cooling box).

Ikan patin yang diambil sebagai sampel adalah ikan sakit, ikan diduga sakit, ikan (sakit) baru saja mati, dan ikan segar. Sampel yang diambil berjumlah 9 (sembilan) ekor (SNI 7306 : 2009). Perhitungan jumlah sampel satu stasiun dengan 3 (tiga) kali ulangan adalah 27 ekor. Secara keseluruhan jumlah sampel yang diperiksa secara eksitu sebanyak 81 ekor pengambilan sampel dilakukan secara acak, selanjutnya sampel air diambil beriringan dengan pengukuran kualitas air secara insitu dan dilakukan secara grab sampling. Frekuensi pengambilan sampel sepuluh (10) hari sekali dan dilakukan pengulangan sebanyak tiga kali.

\section{Pemeriksaan Bakteri E.coli dari Air Sungai}

Pengambilan sampel air dan pengujian E. coli berpedoman pada SNI 01-2332-.1-2006 tentang cara uji mikrobiologi dalam penentuaan E.coli. Pemeriksaan total bakteri E.coli dimulai dengan mengambil 1 $\mathrm{mL}$ air sampel selanjutnya dimasukan ke dalam tabung reaksi bertutup ulir yang telah berisi aquades steril sebanyak $9 \mathrm{~mL}$ lalu dihomogenisasi menggunakan vortex mixer selama 3-5 menit selanjutnya dilakukan inokulasi dan isolasi bakteri menggunakan teknik spread plate dan streak plate (cawan tebar dan cawan gores) pada media Plate Count Agar (PCA) dan teknik pengenceran sampai $10^{4}$ kali. Penghitungan bakteri menggunakan metode TPC (total plate count), dengan menghitung jumlah unit koloni $\mathrm{cfu} / \mathrm{mL}$ (Badjoeri, 2008).

\section{Pemeriksaan Bakteri Patogen pada Ikan Patin}

Metode pemeriksaan bakteri dilakukan secara konvensional dengan pengujian secara biokimia. Pemeriksaan bakterial dilakukan untuk mengidentifikasikan bakteri yang diduga merupakan penyebab terjadinya suatu penyakit. Target isolasi bakteri adalah luka (eksternal) dan organ dalam (internal) adalah hati, jatung dan ginjal dengan cara menggunakan jarum ose yang sudah disterilkan dengan api bunsen, kemudian diinokulasikan pada media agar pada cawan petri. Kemudian diinkubasikan pada suhu $25-28^{\circ} \mathrm{C}$ selama 18-24 jam, setelah itu dilakukan pemurnian hingga mendapatkan koloni tunggal baru dilakukan uji biofisika maupun uji biokimia (Lukistyowati, 2005). Identifikasi berdasarkan acuan Bergey's Manual of Systematic bacteriology dan Cowan And Steel's Manual For The Identification Of Medical Bacteria. 


\section{Pemeriksaan Kualitas Air}

Metode pengambilan contoh uji kualitas air berpedoman pada SNI 06-2412-1991 tentang titik Pengambilan contoh air dengan menggunakan alat berupa Bottle Water Sampler volume 1 liter yaitu pada permukaan air. Pengukuran parameter kecerahan, oksigen terlarut, suhu dan $\mathrm{pH}$ diperoleh dengan cara mengukur langsung di lapangan (insitu), untuk beberapa parameter nitrit, nitrat, fosfat, amonia, TSS dan BOD sampel air dimasukan ke dalam botol steril berwarna gelap dan dimasukan ke dalam cool box yang telah diberi es, kemudian dibawa untuk dianalisa di laboratorium (eksitu).

\section{Analisis Data}

Hasil perhitungan kelimpahan bakteri E.coli yang diperoleh dibandingkan dengan Peraturan Pemerintah Indonesia No 82 Tahun 2001 tentang Pengelolaan Kualitas Air dan Pengendalian Pencemaran Air serta literatur terkait. Data yang diperoleh kemudian dibahas secara deskriptif untuk diambil kesimpulan penentuan status kualitas lingkungan perairan tersebut. Data hasil identifikasi bakteri patogen pada ikan dianalisis dengan menggunakan prevalensi/frekuensi kejadian. data rerata kualitas air dan persentase kejadian penyakit (prevalensi) dianalisis dengan regresi linear berganda dan korelasi. Tingkat korelasi akan dinyatakan dalam koefisien determinasi (Sugiyono, 2012). Pada analisa data regresi antara kualitas air dan jumlah kejadian penyakit, variabel tidak bebas $(\mathrm{Y})$ yang digunakan adalah jumlah kejadian penyakit dan parameter kualitas air sebagai variabel bebas (X).

\section{HASIL DAN PEMBAHASAN}

\section{Keadaan Umum Lokasi Penelitian}

Ikan yang dipelihara dikeramba merupakan komiditi perikanan yang memiliki ekonomis penting seperti ikan patin, tapah, baung, toman dan ikan nila. Pada bagian sisi kiri dan sisi kanan aliran sungai sepanjang $\pm 2 \mathrm{Km}$ terdapat keramba ikan yang berjumlah \pm 329 keramba dengan ukuran beragam yaitu $2 \times 6$ meter, $2 \times 8$ meter dan $2 \times 10$ meter. Selain dimanfaatkan sebagai tempat pemeliharaan ikan juga aliran sungai dimanfatkan sebagai tempat berlangsungnya penangkapan ikan, sarana transportasi , sarana rekreasi memancing, sebagai tempat melakukan kegiatan mandi, cuci dan kakus (MCK). Penelitian dilakukan pada 3 titik sampling dengan karakteristik lokasi sampling berbeda, Titik sampling 1 (Stasiun 1) berada di Dusun I Desa Buluh Cina pada jarak $\pm 1 \mathrm{Km}$ kebagian hulu dari pemukiman penduduk dengan kepadatan keramba berjumlah 20 keramba dan belum ada pemukiman penduduk. Titik Sampling 2 (Stasiun 2) berada di Dusun III Desa Buluh Cina yaitu pada aliran sungai dengan kepadatan keramba bejumlah 216 keramba dan sepanjang bantaran sungai sisi kanan dan kiri aliran sungai terdapat hunian penduduk yang cukup tinggi. Pada Titik sampling 3 (Stasiun 3) berada di Dusun IV Desa Buluh Cina yaitu pada aliran sungai berjarak $\pm 1,2 \mathrm{Km}$ dari stasiun 2. Kepadatan keramba ikan berjumlah 93 keramba dengan tingkat hunian penduduk lebih rendah dari tingkat hunian di stasiun 2 .

\section{Kualitas Air Sungai Buluh Cina}

Kualitas perairan Sungai Kampar di Desa Buluh Cina Secara umum masih memenuhi persyaratan baku mutu air. Namun parameter amonia, nitrit, fosfat dan kelimpahan bakteri E. coli telah melebihi baku mutu berdasarkan pada acuan Peraturan Pemerintah No 82 Tahun 2001. Hasil pengukuran kualitas perairan dapat dilhat pada Tabel 1 .

Tabel 1. Hasil Pengukuran Kualitas Perairan Selama Penelitian

\begin{tabular}{|c|c|c|c|c|c|c|}
\hline \multirow[b]{2}{*}{ Parameter } & \multirow[b]{2}{*}{ Ulangan } & \multicolumn{3}{|c|}{ Stasiun } & \multirow[b]{2}{*}{ Kisaran } & Baku \\
\hline & & St 1 & St 2 & St 3 & & $\begin{array}{c}\text { ( PP } \\
82 / 2001 \\
)\end{array}$ \\
\hline \multirow{4}{*}{ Suhu $\left({ }^{\circ} \mathrm{C}\right)$} & I & 30.2 & 30.5 & 30.7 & \multirow{4}{*}{$29.3-30.7$} & \multirow{4}{*}{$\begin{array}{c}\text { Deviasi } \\
3{ }^{\circ} \mathrm{C}\end{array}$} \\
\hline & II & 29.3 & 30 & 30.2 & & \\
\hline & III & 29.6 & 30.2 & 30.4 & & \\
\hline & Rata-rata & 29.7 & 30.2 & 30.4 & & \\
\hline \multirow{4}{*}{$\begin{array}{c}\text { Kecerahan } \\
(\mathrm{Cm})\end{array}$} & I & 75 & 95 & 70 & \multirow{4}{*}{$70-95$} & \multirow{4}{*}{$\begin{array}{l}(60 \mathrm{~cm}- \\
90 \mathrm{~cm})^{*}\end{array}$} \\
\hline & II & 75 & 80 & 80 & & \\
\hline & III & 80 & 73 & 70 & & \\
\hline & Rata-rata & 76.7 & 82.7 & 73.3 & & \\
\hline
\end{tabular}




\begin{tabular}{|c|c|c|c|c|c|c|}
\hline JURNAL & \multicolumn{3}{|c|}{ Volume 1, Nomor 1, 9-19, 2017} & \multicolumn{3}{|c|}{ ISSN: 2502-6496 (Print) } \\
\hline & \multicolumn{6}{|c|}{ Mumin Rifai et al., 2017. Analisis kelimpahan e.coli ... } \\
\hline \multirow{6}{*}{$\mathrm{pH}$} & I & 5.8 & 5.8 & 5.7 & \multirow{4}{*}{$5.2-5.8$} & \multirow{4}{*}{$6-9$} \\
\hline & II & 5.4 & 5.7 & 5.7 & & \\
\hline & III & 5.2 & 5.5 & 5.6 & & \\
\hline & Rata-rata & 5.5 & 5.7 & 5.7 & & \\
\hline & I & 6.5 & 7.2 & 7.5 & \multirow{4}{*}{$5.8-6.79$} & \\
\hline & II & 6.06 & 6.42 & 6.73 & & \multirow{3}{*}{4} \\
\hline \multirow{3}{*}{$\mathrm{DO}(\mathrm{mg} / \mathrm{L})$} & III & 6.79 & 5.8 & 5.8 & & \\
\hline & Rata-rata & 6.5 & 6.5 & 6.7 & & \\
\hline & I & 4.347 & 2.86 & 4.533 & \multirow{4}{*}{$\begin{array}{c}2,572- \\
5,237\end{array}$} & \\
\hline \multirow{3}{*}{ Nitrat (mg/L) } & II & 3.816 & 3.152 & 5.516 & & \multirow{3}{*}{10} \\
\hline & III & 4.404 & 2.572 & 5.237 & & \\
\hline & Rata-rata & 4.2 & 2.9 & 5.1 & & \\
\hline \multirow{4}{*}{ Nitrit (mg/L) } & I & 0.052 & 0.105 & 0.016 & \multirow{4}{*}{$\begin{array}{c}0,006- \\
0,125\end{array}$} & \\
\hline & II & 0.092 & 0.125 & 0.023 & & \multirow{3}{*}{0,06} \\
\hline & III & 0.059 & 0.115 & 0.006 & & \\
\hline & Rata-rata & 0.068 & 0.115 & 0.015 & & \\
\hline \multirow{4}{*}{ Amonia $(\mathrm{mg} / \mathrm{L})$} & I & 0.036 & 0.054 & 0.021 & \multirow{4}{*}{$\begin{array}{c}0,015- \\
0,076\end{array}$} & \multirow{3}{*}{$(-) * *$} \\
\hline & II & 0.045 & 0.046 & 0.015 & & \\
\hline & III & 0.028 & 0.076 & 0.018 & & \\
\hline & Rata-rata & 0.036 & 0.059 & 0.018 & & \\
\hline \multirow{4}{*}{ Fosfat (mg/L) } & I & 7.781 & 9.996 & 5.616 & \multirow{4}{*}{$\begin{array}{l}4,440- \\
10,724\end{array}$} & \multirow{4}{*}{0,2} \\
\hline & II & 8.262 & 8.693 & 4.440 & & \\
\hline & III & 7.678 & 10.724 & 4.708 & & \\
\hline & Rata-rata & 7.907 & 9.804 & 4.921 & & \\
\hline \multirow{4}{*}{ TSS (mg/L) } & I & 10 & 5 & 10 & \multirow{4}{*}{$2-16$} & \multirow{4}{*}{50} \\
\hline & II & 5 & 13 & 9 & & \\
\hline & III & 2 & 13 & 16 & & \\
\hline & Rata-rata & 6 & 10 & 12 & & \\
\hline \multirow{4}{*}{$\mathrm{BOD}_{5}(\mathrm{mg} / \mathrm{L})$} & I & 3.1 & 4.2 & 0.3 & \multirow{4}{*}{$0,03-4,2$} & \multirow{4}{*}{3} \\
\hline & II & 2.3 & 3.6 & 3.8 & & \\
\hline & III & 0.48 & 3 & 3.4 & & \\
\hline & Rata-rata & 1.96 & 3.6 & 2,50 & & \\
\hline & I & 8.500 & 9.100 & 8.900 & & \\
\hline Kelimpahan $E$. & II & 2.700 & 5.500 & 4.300 & $1.400-$ & \\
\hline Coli & III & 1.400 & 3.700 & 3.300 & 9.100 & 2.000 \\
\hline & Rata-rata & 4.200 & 6.100 & 5.500 & & \\
\hline
\end{tabular}

Kondisi suhu pada saat pengukuran, ulangan I di setiap stasiun menunjukan angka yang paling tinggi yaitu berkisar $30,2-30,7{ }^{\circ} \mathrm{C}$ dan suhu terendah tedapat pada ulangan II berkisar suhu antara 29,3 $-30,2^{\circ} \mathrm{C}$. Fluktuasi suhu pada setiap ulangan dan disetiap stasiun $\pm 1^{\circ} \mathrm{C}$, suhu terendah terdapat pada stasiun 2 dan tertinggi di stasiun 3. Suhu optimum yang dianjurkan dalam pemeliharaan ikan air tawar adalah pada kisaran suhu $25-30{ }^{\circ} \mathrm{C}$ ( Efendi, 2003) dan Menurut Maniagasi et al (2013) menyatakan suhu suatu perairan ditentukan oleh beberapa faktor antara lain ketinggian suatu daerah, curah hujan yang tinggi dan intensitas cahaya matahari yang menembus suatu perairan.

Hasil pengukuran kecerahan berkisar 70-95 cm, kecerahan ini dipengaruhi oleh aktifitas masyarakat pada staiun 1 dan stasiun 2 seperti budidaya keramba ikan dan aktifitas domestik. Perairan yang memiliki kecerahan 0,60 M - 0,90 M dianggap cukup baik untuk menunjang kehidupan ikan dan organisme lainnya, akan tetapi jika kecerahan $<0,30 \mathrm{M}$ dapat menimbulkan masalah bagi ketersediaan oksigen terlarut di perairan (Boyd, 1990).

Nilai TSS yang diperoleh pada stasiun 1 berkisar antara 2-10 mg/L, stasiun 2 diperoleh nilai 5-13 $\mathrm{mg} / \mathrm{L}$ dan stasiun 3 berkisar antara $9-16 \mathrm{mg} / \mathrm{L}$. Nilai TSS tertinggi pada di stasiun 3 dikarenakan oleh akumulasi dari daerah hulu. Menurut baku mutu air Kelas II, kandungan residu tersuspensi yang dianjurkan adalah sebesar $50 \mathrm{mg} / \mathrm{L}$ jadi kisaran nilai yang diperoleh pada semua stasiun pengamatan masih berada dalam kisaran yang diperbolehkan untuk kegiatan perikanan. Nilai $\mathrm{pH}$ berkisar 5,2 - 5,8 adanya perbedaan setiap stasiun dan setiap ulangan tidak jauh berbeda, pengaruh $\mathrm{pH}$ bersifat asam ini terlepas dari alamiah perairan sungai di Provinsi Riau yang mempunyai karakter sumber air berasal dari 
daerah rawa/gambut. Kecenderungan $\mathrm{pH}$ bersifat asam tersebut diperkuat oleh pernyataan Syaukani (2009) yang menyatakan bahwa pada dasarnya $\mathrm{pH}$ air tanah yang berada di lahan gambut adalah bersifat asam ( $\mathrm{pH}$ 3,0-5,0). Nilai Oksigen terlarut (DO) berkisar 5,8 - 6,79 mg/L. Nilai DO Sungai Kampar di Desa Buluh Cina ditinjau dari nilai kisaran dan nilai rerata masing-masing stasiun serta nilai rerata setiap ulangan masih sangat mendukung untuk kehidupan organisme air karena nilai hasil pengukuran berada pada nilai DO diatas $4 \mathrm{mg} / \mathrm{L}$. Menurut Nurachmi (1999) mengemukakan bahwa pada suatu perairan organisme dapat hidup dengan layak jika kandungan oksigen terlarut tidak kurang dari $4 \mathrm{mg} / \mathrm{L}$. Menurut Effendi (2003) menyatakan secara ekologis konsentrasi oksigen terlarut menurun dengan adanya penambahan bahan organik, karena bahan organik tersebut akan diuraikan oleh mikroorganisme yang mengkonsumsi oksigen yang tersedia. Menurut PP 28 Tahun 2001 Kelas II dan III, kandungan DO yang dianjurkan adalah sebesar 3-4 $\mathrm{mg} / \mathrm{L}$.

Nilai amonia berkisar antara 0,015 - 0,076 mg/L, nilai tersebut sudah melebihi ambang batas dimana Minggawati dan Lukas (2012) menyatakan bahwa kadar amonia bebas yang melebihi 0,2 mg/L bersifat racun bagi beberapa jenis ikan, selain itu kadar amonia yang tinggi dapat di jadikan sebagai indikasi adanya pencemaran bahan organik yang berasal dari limbah domestik dan limpasan pupuk pertanian adapun sumber ammonia di perairan adalah hasil dari pemecahan nitrogen organik berupa tumbuhan dan biota akuatik yang telah mati. Hasil pengukuran nitrat diperoleh kisaran nilai 2,572 - 5,237 $\mathrm{mg} / \mathrm{L}$. Pujiastuti et al (2013) menyatakan nitrat merupakan salah satu bentuk nitrogen yang larut dalam air. Pencemaran dari pemupukan, kotoran hewan dan manusia merupakan penyebab tingginya kadar nitrat. Sedangkan Kurniawan (2012) mengatakan nitrat adalah bentuk utama dari nitrogen di perairan alami dan merupakan nutrien utama bagi pertumbuhan tanaman dan alga. Kadar nitrat di perairan tidak tercemar biasanya lebih tinggi daripada kadar amonia. Nitrat sangat mudah larut dalam air dan bersifat stabil, sedangkan nitrit biasanya ditemukan dalam jumlah yang sangat sedikit di perairan karena bersifat tidak stabil terhadap keberadaan oksigen. Menurut PP 28 Tahun 2001 Kelas II dan III, kandungan nitrat yang dianjurkan adalah sebesar 10-20 $\mathrm{mg} / \mathrm{L}$.

Hasil pengukuran nitrit diperoleh nilai dengan kisaran $0,006-0,125 \mathrm{mg} / \mathrm{L}$. Nilai tertinggi nitrit dari hasil pengukuran di perairan sungai yaitu pada kosentrasi $0,125 \mathrm{mg} / \mathrm{L}$, ini dapat membahayakan kehidupan organisme akuatik karena Menurut Boyd (1990) menyatakan Kadar nitrit lebih dari 0,05 mg/L bersifat toksik bagi organisme akuatik yang sensitif. Nitrit lebih bersifat toksik dibandingkan nitrat terhadap hewan dan manusia. Tingginya kosentrasi nitrit di duga oleh limbah pakan berupa pelet, pakan ikan dari limbah ayam, aktifitas domestik rumah tangga dan aktifitas dari pemupukan sawit. Limbah tersebut menghasil nitrogen namun tidak terdekomposisi dengan baik oleh mikroba sehingga nilai kosentrasi nitrit menjadi meningkat. Menurut Ferdiansyah (2015) menyatakan pakan yang diberikan untuk ikan mas dalam keramba jaring apung tidak terkontrol jumlahnya sehingga penumpukan sisa pakan yang mengandung unsur nitrogen tidak terdekomposisi secara sempurna oleh mikroba dan adanya aktivitas perkebunan disekitar waduk Koto Panjang yang menggunakan pupuk ikut menyumbang limbah yang masuk kedalam waduk sehingga meningkatkan nilai nitrit di Waduk Koto Panjang.

Nilai $\mathrm{BOD}_{5}$ berkisar antara 0,03 - 4,2 mg/L. Tingginya nilai BOD pada Stasiun 2 ulangan I ini diduga bahwa stasiun tersebut aktifitas kegiatan pemberian pakan berupa pelet dan limbah ayam sebagai makanan ikan berlebih dan tidak terkontrol, serta limbah domestik rumah tangga ikut mencemari perairan sungai. Merujuk pada PP 28/2001 Kelas II dan III BOD hasil pengukuran pada Sungai Kampar Buluh Cina masih memenuhi standar baku mutu. Nilai fosfat berkisar antara 4,440 - 10,724 mg/L menurut Pujiastuti et al (2013) menyatakan bahwa fosfat merupakan bentuk fosfor yang dapat dimanfaatkan oleh tumbuhan dan merupakan unsur yang esensial bagi tumbuhan, sehingga menjadi faktor pembatas yang mempengaruhi produktivitas perairan. Fosfat yang terdapat di perairan bersumber dari air buangan penduduk (limbah rumah tangga) berupa deterjen, residu hasil pertanian (pupuk), limbah industri, hancuran bahan organik dan mineral fosfat. Umumnya kandungan fosfat dalam perairan alami sangat kecil dan tidak pernah melampaui $0,1 \mathrm{mg} / 1$, kecuali bila ada penambahan dari luar oleh faktor antropogenik seperti dari sisa pakan ikan dan limbah pertanian (Pujiastuti et al, 2013).

\section{Kelimpahan Bakteri E.coli}

Hasil isolasi dan identifikasi terhadap air sungai dari setiap stasiun pengamatan bulan agustus 2015 pada 3 kali ulangan dengan interval waktu 10 hari sekali ditemukan kelimpahan bakteri E. coli berkisar $1.400-9.100 \mathrm{cfu} / 100 \mathrm{ml}$. Kelimpahan tertinggi berada pada staisun 2 dan terendah berada pada 
stasiun 1. Nilai kelimpahan rerata setiap stasiun adalah Stasiun 1 (4.200 cfu/100 ml), Stasiun 2 (6.100 $\mathrm{cfu} / 100 \mathrm{ml})$ dan Stasiun 3 (5.500 cfu /100 ml).

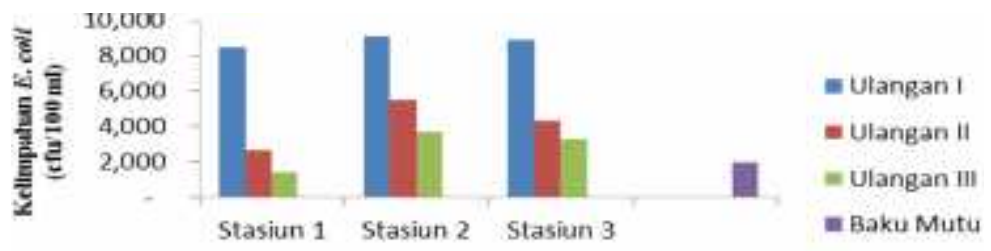

Stasiun Pengamatan

Gambar 1. Kelimpahan E.coli pada Stasiun Penelitian

Menurut Entjang (2003) menyatakan Escherichia coli tergolong pada bakteri coliform ini merupakan flora normal didalam usus manusia dan akan menimbulkan penyakit bila masuk kedalam organ atau jaringan lain, seperti pneumonia, endocarditis, infeksi pada luka, abses pada berbagai organ, meningitis dan dapat menyebabkan penyakit diare. Sedangkan menurut Laydy et al (2014) menyatakan Bakteri Escherichia merupakan bakteri yang dapat hidup pada usus hewan mamalia termasuk manusia. Penyebaran kotoran baik manusia dan hewan yang tidak terkontrol dalam lingkungan perairan dapat menyebabkan lingkungan perairan tercemar oleh bakteri ini.

\section{Prevalensi Bakteri Patogen pada Ikan Patin}

Sampel ikan patin yang diambil dari masing masing stasiun secara acak kemudian dilakukan isolasi dan diidentifikasi, hasil bakteri yang didapat pada ikan patin disajikan pada Tabel 2 .

Tabel 2. Jenis Bakteri yang Ditemukan pada Sampel Ikan Patin

\begin{tabular}{|c|c|c|c|c|c|}
\hline \multirow{2}{*}{ No } & \multirow{2}{*}{ Lokasi Sampling } & \multirow{2}{*}{ Bakteri yang ditemukan } & \multicolumn{3}{|c|}{ Target Organ } \\
\hline & & & Ginjal & Hati & Jantung \\
\hline & \multirow[t]{9}{*}{ Stasiun I } & Pseudomonas shigelloides & - & $\sqrt{ }$ & $\sqrt{ }$ \\
\hline & & Edwardsiella tarda & $\sqrt{ }$ & $\sqrt{ }$ & $\sqrt{ }$ \\
\hline & & Alcaliganes faecalis & $\sqrt{ }$ & $\sqrt{ }$ & - \\
\hline & & Aeromonas hydrophila & $\sqrt{ }$ & $\sqrt{ }$ & $\sqrt{ }$ \\
\hline & & Flavobacterium $s p$ & $\sqrt{ }$ & - & - \\
\hline & & Pseudomonas putides & $\sqrt{ }$ & - & - \\
\hline & & Chromobacerium sp & - & - & $\sqrt{ }$ \\
\hline & & Aeromonas sorbia & - & - & $\sqrt{ }$ \\
\hline & & Pasteurella sp & & & \\
\hline & \multirow{10}{*}{ Stasiun II } & Pasteurella sp & - & - & $\sqrt{ }$ \\
\hline & & Pseudomonas putides & $\sqrt{ }$ & $\sqrt{ }$ & $\sqrt{ }$ \\
\hline & & Alcaliganes faecalis & - & - & $\sqrt{ }$ \\
\hline & & Aeromonas sorbia & $\sqrt{ }$ & $\sqrt{ }$ & - \\
\hline & & Aeromonas caviae & $\sqrt{ }$ & $\sqrt{ }$ & - \\
\hline & & Chromobacerium sp & - & $\sqrt{ }$ & - \\
\hline & & Aeromonas hydrophila & - & $\sqrt{ }$ & $\sqrt{ }$ \\
\hline & & Pseudomonas shigelloides & $\sqrt{ }$ & - & $\sqrt{ }$ \\
\hline & & Flavobacterium sp & $\sqrt{ }$ & $\sqrt{ }$ & $\sqrt{ }$ \\
\hline & & Edwardsiella tarda & - & - & $\sqrt{ }$ \\
\hline & \multirow[t]{8}{*}{ Stasiun III } & Edwardsiella tarda & $\sqrt{ }$ & $\sqrt{ }$ & - \\
\hline & & Aeromonas caviae & - & $\sqrt{ }$ & - \\
\hline & & Alcaliganes faecalis & - & $\sqrt{ }$ & - \\
\hline & & Pseudomonas shigelloides & - & - & $\sqrt{ }$ \\
\hline & & Aeromonas sorbia & - & - & $\sqrt{ }$ \\
\hline & & Flavobacterium $s p$ & - & $\sqrt{ }$ & $\sqrt{ }$ \\
\hline & & Pasteurella $s p$ & $\sqrt{ }$ & - & $\sqrt{ }$ \\
\hline & & Aeromonas hydrophila & $\sqrt{ }$ & - & $\sqrt{ }$ \\
\hline
\end{tabular}




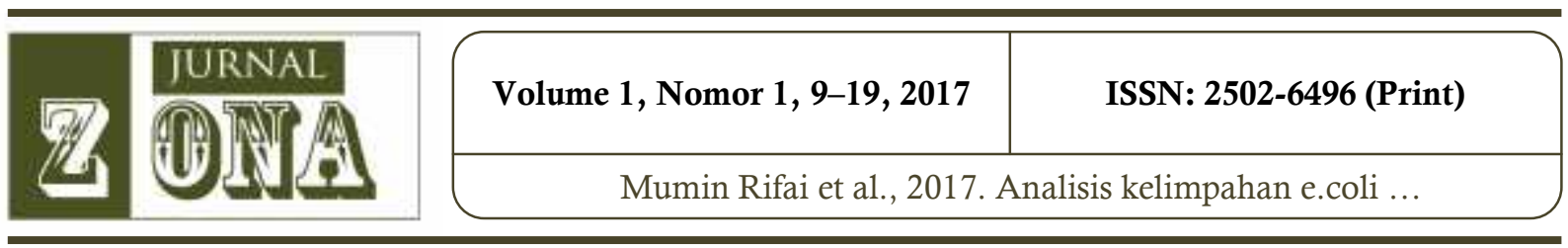

Hasil bakteri yang teridentifikasi sebanyak sepuluh Genus yang berasal dari seluruh stasiun pengamatan dan tergolong kedalam golongan bakteri Gram Negatif. Nilai prevalensi tertinggi terjadi pada bakteri golongan Aeromonas sp sebesar 29,63 \% pada stasiun 2. Berdasarkan hasil nilai prevalensi bakteri patogen yang ditemukan, nilai tertinggi menunjukkan bahwa bakteri Aeromonas sp lebih sering menyerang dan mengganggu kesehatan ikan dibandingkan dengan bakteri patogen lainnya. Bakteri ini umumnya hidup diperairan tawar terutama yang mengandung bahan organik yang tinggi. Menurut Badjoeri (2008) Aeromonas sp, Vibrio sp, dan Pseudomonas sp merupakan jenis bakteri yang bersifat patogenik pada ikan, menyebar secara cepat pada padat penebaran tinggi dan dapat mengakibatkan kematian ikan sampai $90 \%$. Prevalensi bakteri patogen yang menyerang ikan patin selama penelitian pada Tabel 3 dan Gambar 2.

\begin{tabular}{|c|c|c|c|c|c|}
\hline No & $\begin{array}{c}\text { Titik } \\
\text { Sampling }\end{array}$ & $\begin{array}{l}\text { Jenis Bakteri } \\
\text { Patogen }\end{array}$ & $\begin{array}{c}\text { Jumlah Sampel } \\
\text { yang diperiksa } \\
\text { (ekor) }\end{array}$ & $\begin{array}{c}\text { Jumlah Sampel } \\
\text { yang terinfeksi } \\
\text { (ekor) }\end{array}$ & $\begin{array}{l}\text { Nilai Prevalensi } \\
(\%)\end{array}$ \\
\hline \multirow[t]{4}{*}{1} & Stasiun 1 & Aeromonas sp & \multirow{4}{*}{27} & 3 & 11,11 \\
\hline & & Pseudomonas sp & & 1 & 3,70 \\
\hline & & Pasteurella sp & & 1 & 3,70 \\
\hline & & Edwarsiella sp & & 4 & 14,81 \\
\hline \multirow[t]{4}{*}{2} & Stasiun 2 & Aeromonas sp & \multirow{4}{*}{27} & 8 & 29,63 \\
\hline & & Pseudomonas sp & & 3 & 11,11 \\
\hline & & Pasteurella sp & & 2 & 7,41 \\
\hline & & Edwarsiella sp & & 1 & 3,70 \\
\hline \multirow[t]{4}{*}{3} & Stasiun 3 & Aeromonas sp & \multirow{4}{*}{27} & 5 & 18,52 \\
\hline & & Pseudomonas sp & & 0 & 0 \\
\hline & & Pasteurella sp & & 3 & 11,11 \\
\hline & & Edwarsiella sp & & 3 & 11,11 \\
\hline & \multirow{4}{*}{\multicolumn{2}{|c|}{ 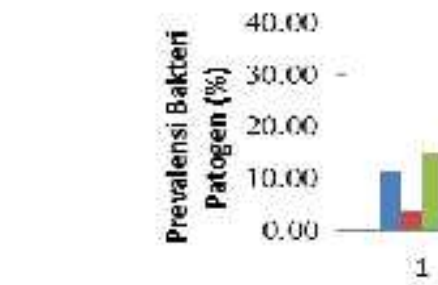 }} & & \multirow{4}{*}{$\begin{array}{l}\text { Aeromonas sp } \\
=\text { Pseud ocnumas sp } \\
=\text { Fotwarsiclla } \mathrm{sp} \\
=\text { Pasteurella sp }\end{array}$} & \\
\hline & & & & & \\
\hline & & & & & \\
\hline & & & 2 & & \\
\hline
\end{tabular}

Gambar 2. Prevalensi Bakteri Patogen pada Ikan Patin

Korelasi Antara Kualitas Perairan dengan Prevalensi Bakteri Patogen dan Kelimpahan E. Coli.

Bakteri Aeromonas sp lebih sering menyerang dan mengganggu kesehatan ikan dibandingkan dengan bakteri patogen lainnya dan umumnya hidup di perairan tawar terutama yang mengandung bahan organik yang tinggi. Berdasarkan hasil analis regresi berganda antara prevalensi Aeromonas sp dengan parameter fisika kualitas perairan diperoleh persamaan regresi sebagai berikut :

$$
\mathrm{Y}=51.756-2,072 \mathrm{x}_{1}+0,147 \mathrm{x}_{2}+0,828 \mathrm{x}_{3}
$$

Didapatkan nilai $\mathrm{r}=0,622, \mathrm{r}^{2}=0,387$ dan nilai signifikan 0,446 . Nilai korelasi yang diperoleh antara bakteri Aeromonas sp dengan parameter kimia kualitas air diperoleh nilai $\mathrm{r}=$ $0,889, \mathrm{r}^{2}=0,790$ dan nilai signifikan 0,785 dengan persamaan regresi sebagai berikut :

$$
Y=211,901-31,954 x_{1}-5,476 x_{2}+8,156 x_{3}+327,36 x_{4}+190,65 x_{5}+1,108 x_{6}-12,74 x_{7}
$$

Parameter kualitas perairan yang telah melebihi ambang batas dari baku mutu yang dipersyaratkan antara lain nitrit dan ammonia memiliki korelasi yang rendah terhadap prevalensi bakteri Aeromonas sp, dimana nilai koefisien korelasi nitrit yang didapat sebesar 0,367 dan nilai koefisien korelasi ammonia sebesar 0,354. 

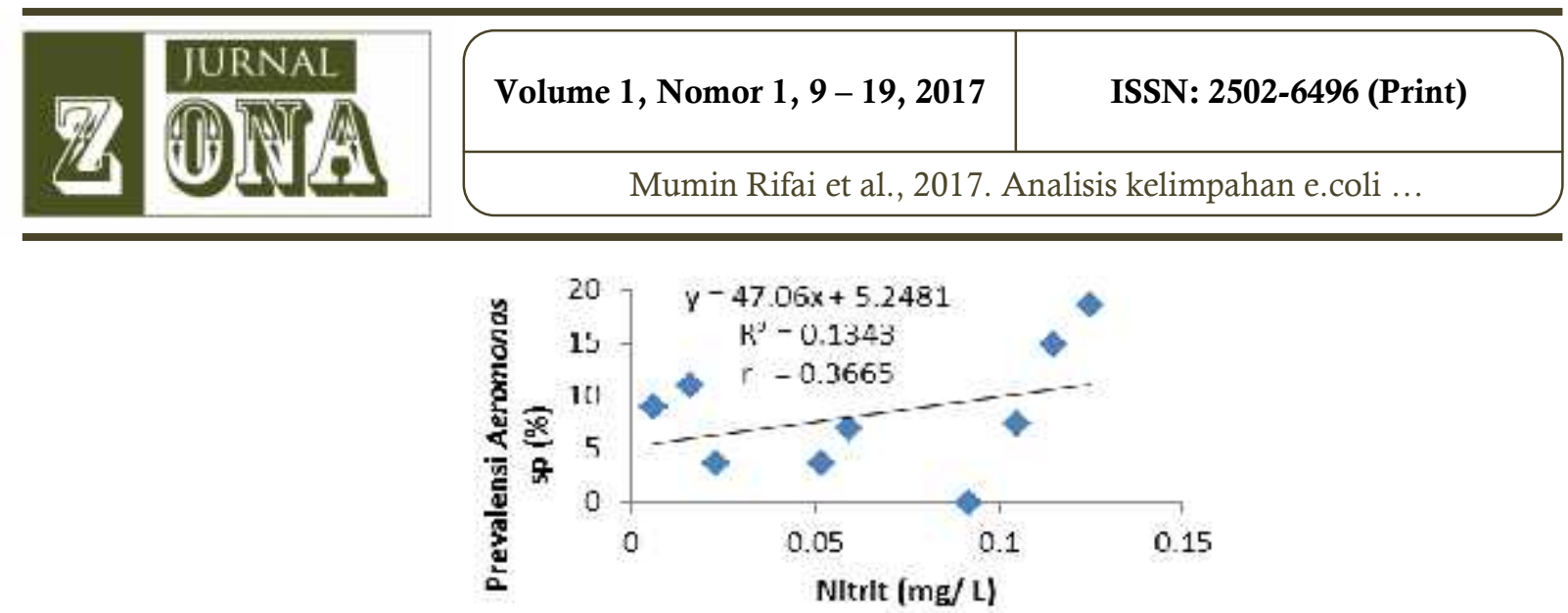

Gambar 3. Hubungan antara nitrit dengan Prevalensi bakteri Aeromonas sp pada ikan patin

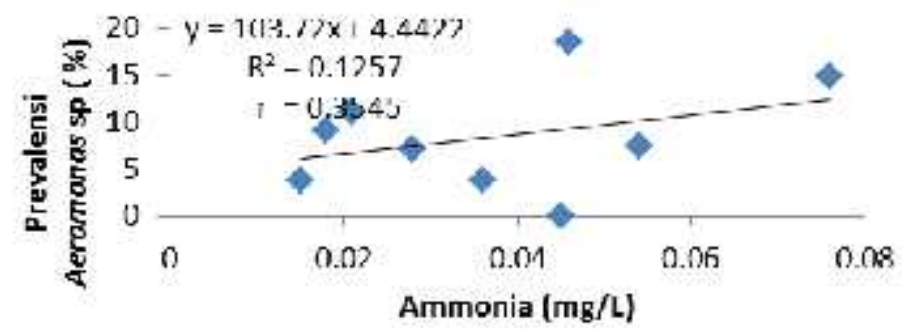

Gambar 4. Hubungan antara Ammonia dengan Prevalensi bakteri Aeromonas sp pada ikan patin

Hubungan antara parameter fisika kualitas perairan dengan prevalensi bakteri Pseudomonas sp didapat nilai $\mathrm{r}$ sebesar 0,661 dan $\mathrm{r}^{2}$ sebesar 0,437 dengan nilai signifikansi sebesar 0,373 dengan persamaan regresi sebagai berikut :

$$
\mathrm{Y}=41,152-1,675 \mathrm{x}_{1}+0,150 \mathrm{x}_{2}-0,075 \mathrm{x}_{3}
$$

Parameter kimia perairan yang diukur diperoleh nilai $r$ sebesar $0,846 \mathrm{r}^{2}$ sebesar 0,715 dan nilai signifikansi sebesar 0,861 . Persamaan regresi yang didapat adalah sebagai berikut :

$$
Y=29,305+7,741 x_{1}-5,033 x_{2}-10,042 x_{3}-159,278 x_{4}-148,972 x_{5}-0,703 x_{6}+4,4472 x_{7}
$$

Nilai nitrit dan ammonia memiliki korelasi yang kuat terhadap prevalensi bakteri Pseudomonas sp, dimana nilai koefisien korelasi nitrit yang didapat sebesar 0,585 dan nilai koefisien korelasi ammonia sebesar 0,681 terhadap prevalensi Pseudomonas sp dan koefisien determinasi nitrit sebesar 34,2\% mempengaruhi prevalensi Pseudomonas sp dan koefisien determinasi amonia sebesar 46,3\% mempengaruhi prevalensi Pseudomonas sp seperti pada Gambar 5 dan 6.

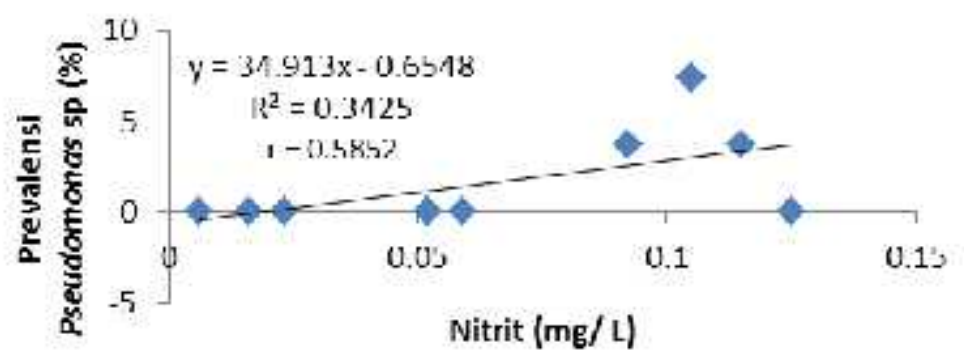

Gambar 5. Hubungan antara nitrit dengan Prevalensi bakteri Pseudomonas sp pada ikan patin 


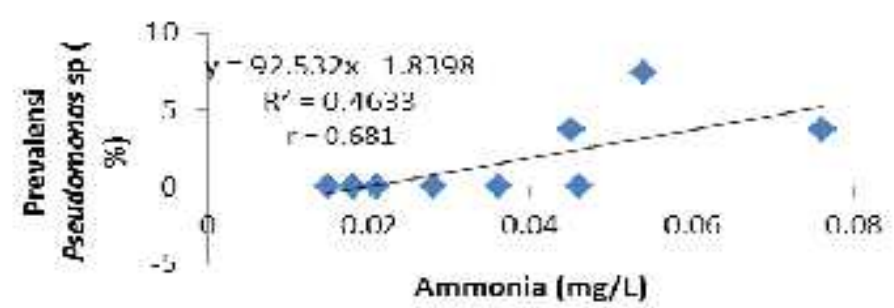

Gambar 6. Hubungan antara ammonia dengan Prevalensi bakteri Pseudomonas sp pada ikan patin

Hubungan antara parameter fisika kualitas perairan dengan prevalensi bakteri Edwardsiella sp didapat nilai $\mathrm{r}$ sebesar 0,861 dan $\mathrm{r}^{2}$ sebesar 0,742 dengan nilai signifikansi sebesar 0,620 dan diperoleh persamaan regresi sebagai berikut :

$$
Y=-3,954+0,966 x_{1}-0,246 x_{2}-0,303 x_{3}
$$

Parameter kimia perairan yang diukur diperoleh nilai $\mathrm{r}$ sebesar 0,990 $\mathrm{r}^{2}$ sebesar 0,981 dan nilai signifikansi sebesar 0,279. Persamaan regresi yang didapat adalah sebagai berikut :

$$
Y=-55,775+12,419 x_{1}+0,711 x_{2}-3,485 x_{3}-102,317 x_{4}+173,306 x_{5}-3,005 x_{6}+3,950 x_{7}
$$

Nilai koefisien korelasi nitrit yang didapat sebesar 0,367 dan nilai koefisien korelasi amonia sebesar 0,182 terhadap prevalensi Edwardsiella sp dan koefisien determinasi nitrit sebesar 13,4\% mempengaruhi prevalensi Edwardsiella sp dan koefisien determinasi amonia sebesar 3\% mempengaruhi prevalensi Edwardsiella sp seperti pada Gambar 7 dan 8.

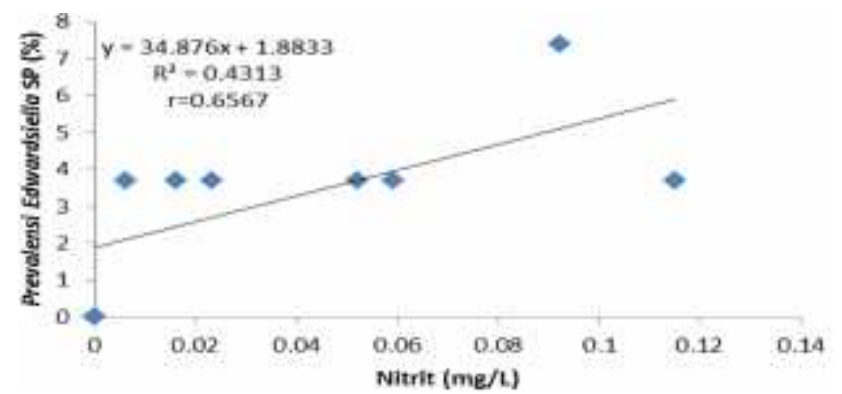

Gambar 7. Hubungan antara Nitrit dengan Prevalensi bakteri Edwardsiella sp pada ikan patin

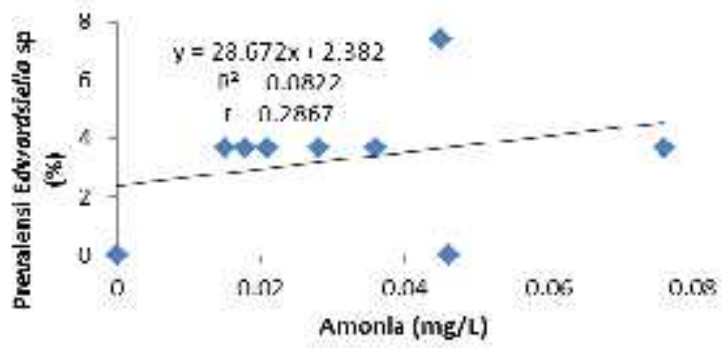

Gambar 8. Hubungan antara Ammonia dengan Prevalensi bakteri Edwardsiella sp pada ikan patin

Korelasi antara prevalensi bakteri $E$. coli dengan parameter fisika perairan didapatkan nilai $\mathrm{r}=0,821$ , $\mathrm{r}^{2}=0,674$ dan nilai signifikan 0,108. Persamaan regresi yang didapat adalah sebagai berikut:

$$
\mathrm{Y}=-142392.603+4864.611 \mathrm{x}_{1}+41.492 \mathrm{x}_{2}--226.795 \mathrm{x}_{3}
$$

Nilai korelasi yang diperoleh antara bakteri E. Coli dengan parameter kimia kualitas air yang diukur didapatkan nilai $\mathrm{r}=0,970, \mathrm{r}^{2}=0,940$ dan nilai signifikan 0,473 dengan persamaan regresi sebagai berikut:

$$
\begin{gathered}
Y=-93456.071+9215.396 x_{1}+2102.122 x_{2}+3390.805 x_{3}+2866.172 x_{4}-29759.529 x_{5}+865.012 x_{6}+ \\
2762.529 x_{7}
\end{gathered}
$$


Nilai koefisien korelasi nitrit yang didapat sebesar 0,262 dan nilai koefesien korelasi ammonia sebesar 0,107 terhadap kelimpahan bakteri E.coli dan koefesien determinasi 27,83\% mempengaruhi kelimpahan E. coli dan koefesien determinasi ammonia 1,15\% mempengaruhi kelimpahan $E$. coli seperti pada 9 dan 10 dibawah ini.

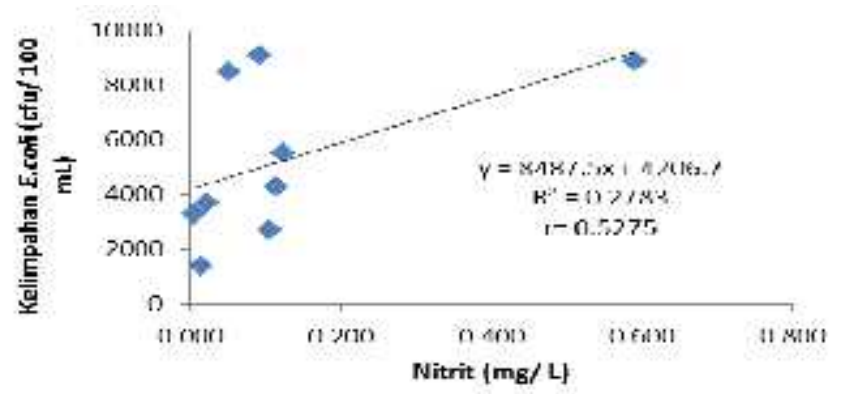

Gambar 9. Hubungan antara Nitrit dengan Kelimpahan bakteri E.coli pada ikan patin

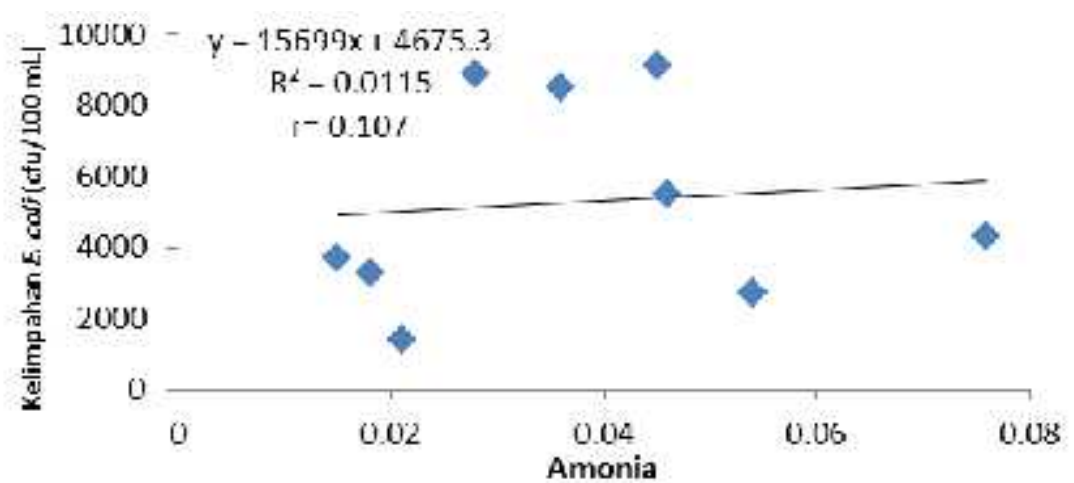

Gambar 10. Hubungan antara Amonia dengan Kelimpahan bakteri E.coli pada ikan patin

\section{KESIMPULAN}

Kondisi perairan secara umum cukup baik dan dalam kisaran baku mutu yang dipersyaratkan sesuai dengan PP No 82 /2001, namun untuk kandungan ammonia sudah melewati nilai ambang batas yaitu nilai rata-rata mencapai $0,018-0,059 \mathrm{mg} / \mathrm{L}$, fosfat pada nilai rata-rata $4,921-9,804 \mathrm{mg} / \mathrm{L}$ dan Kandungan nitrit $\left(\mathrm{NO}_{2}\right)$ nilai rata-rata $0,015-0,068 \mathrm{mg} / \mathrm{L}$. Kelimpahan Bakteri E. coli pada perairan Sungai Kampar yang berada di Desa Buluh Cina rata-rata diperoleh $4.200-5.500 \mathrm{cfu} / 100 \mathrm{ml}$. Bakteri patogen yang ditemukan pada ikan patin adalah Aeromonas sp, Pseudomonas sp, Pasteurella sp dan Edwarsiella sp. Prevalensi yang tertinggi berada pada Aeromonas sp sebesar 29,63 \%. 3. Parameter kimia sangat mempengaruhi terhadap kelimpahan bakteri E. coli sebesar $94 \%$. Kualitas air yang pengaruh paling kuat terhadap E. coli yaitu pada suhu, TSS, pH, dan DO dengan nilai koefesien korelasi $>0,5$. Pada korelasi bakteri patogen dengan kualitas air yang mempunyai hubungan kuat terhadap prevalensi bakteri Aeromonas sp yaitu nitrat dan TSS, Pseudomonas sp dengan suhu, kecerahan, nitrat, nitrit amonia, dan fosfat sedangkan Edwardsiella sp hanya kuat hubungannya dengan suhu dan $\mathrm{pH}$. Mengingat tingginya tingkat pemanfaatan sungai di Desa Buluh Cina maka diperlukan penataan ruang, pembudidaya ikan dalam melakukan pemberian pakan berupa limbah ayam mati dan usus ayam perlu pengolahan terlebih dahulu dengan cara perebusan, mengaplikasikan manajemen pakan yang baik (jenis pakan, cara pemberian pakan, waktu pemberian pakan dan lain-lain) serta perlu dilakukannya penelitian lebih lanjut.

\section{UCAPAN TERIMAKASIH}

Penulis menyampaikan terimakasih kepada seluruh pihak yang membantu dalam kelancaran penelitian ini. 


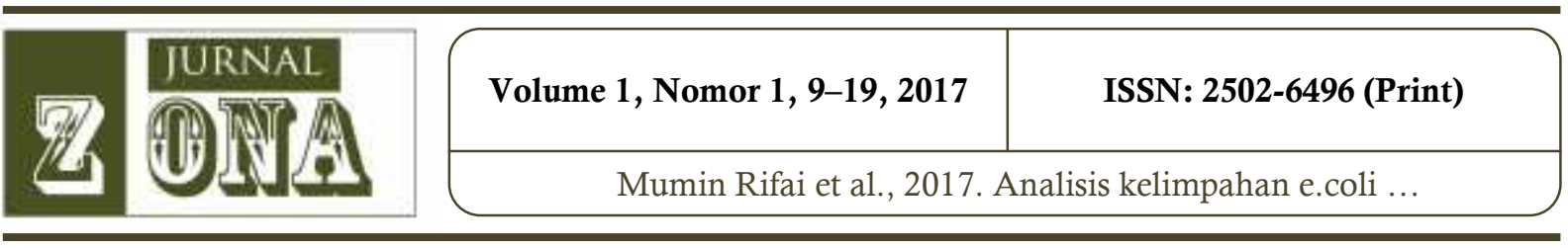

\section{DAFTAR PUSTAKA}

Badjoeri, M. 2008. Identifikasi Bakteri Patogen pada Sistem Keramba Jaring Apung (KJA) di Danau Maninjau Sumatera Barat. Pusat Penelitian Limnologi LIPI. Jurnal Oseanologi dan Limnologi di Indonesia. 34 (2) 169-184. Jakarta

Boyd, C. E. 1990. Water Quality In Pond For Aquaculture, Birmingham. Publ.Co. Alabama P : 25-186.

Effendi, H. 2003. Telaah Kualitas Air bagi Pengelolaan Sumberdaya dan Lingkungan Perairan. Kanisius. Yogyakarta.

Entjang, I. 2003. Mikrobiologi dan Parasitologi untuk Akademi Keperawatan. Citra Aditya Bakti. Bandung.

Ferdiansyah, R. 2015. Korelasi antara Kualitas Perairan dan Tingkat Prevalensi Bakteri Patogen pada Ikan Mas yang di Budidayakan di Waduk Koto Panjang Kabupaten Kampar. Tesis Program Studi Ilmu Lingkungan. Program Pascasarjana Universitas Riau.

Kurniawan, A. 2012. Penyakit Akuatik. UBB. Pangkalpinang.

Laydy F.H., H. Lalura., Helen., J. Lohoo., Hanny., dan W. Mewengkang. 2014. Identifikasi Bakteri Escherichia Pada Ikan Selar (Selaroides sp.) Bakar di Beberapa Resto di Kota Menado, Jurnal Media Teknologi Hasil Pangan.

Lukistyowati, I. 2005. Teknik Pemeriksaan Penyakit Ikan. Unri. Pekanbaru.

Maniagasi, R, S., Y. Tumembouw dan Mundeng. 2013. Analisis Kualitas Fisika Kimia Air di Areal Budidaya Ikan Danau Tondano Provinsi Sulawesi Utara. Jurnal Budidaya Perairan. 1 (2) 29-37

Minggawati dan Lukas. 2012. Studi Kualitas Air Untuk Budidaya Ikan Karamba di Sungai Kahayan. Jurnal Media Sains. 4 (1) : 87-91.

Nurachmi, I. 1999. Hubungan Konsentrasi Nitrat dan Fosfat dengan Kelimpahan Diatom (Bacillarophyceae) di Perairan Pantai Dumai Barat. Jurnal Perikanan dan Kelautan, Fakultas Perikanan dan Ilmu Kelautan Universitas Riau. Pekanbaru. 4 (12) : 47 - 58.

Pujiastuti, P. B. Ismail dan Pranoto. 2013. Kualitas dan Beban Pencemaran Perairan Waduk Gajah Mungkur. Jurnal EKOSAINS. 5 (1) : 59-75.

Syaukani. 2010. Kualitas Air di Sekitar Areal Usaha Pemanfaatan Hasil Hutan Kayu - Hutan Tanaman Industri Arara Abadi Resort Berbari Kabupaten Siak. Tesis Program Studi Ilmu Lingkungan. Program Pascasarjana Universitas Riau. Pekanbaru. 